\title{
Potentiometric and spectrometric study: Copper(II), nickel(II) and zinc(II) complexes with potentially tridentate and monodentate ligands
}

\author{
R N PATEL*, NRIPENDRA SINGH, R P SHRIVASTAVA, K K SHUKLA \\ and P K SINGH \\ Department of Chemistry, APS University, Rewa 486 003, India \\ e-mail: rnp64@yahoo.co.uk
}

MS received 8 March 2001; revised 7 March 2002

\begin{abstract}
Equilibrium and solution structural study of mixed-metal-mixed-ligand complexes of $\mathrm{Cu}(\mathrm{II}), \mathrm{Ni}(\mathrm{II})$ and $\mathrm{Zn}(\mathrm{II})$ with L-cysteine, L-threonine and imidazole are conducted in aqueous solution by potentiometry and spectrophotometry. Stability constants of the binary, ternary and quaternary complexes are determined at $25 \pm$ $1{ }^{\circ} \mathrm{C}$ and in $I=0 \cdot 1 \mathrm{M} \mathrm{NaClO}_{4}$. The results of these two methods are made selfconsistent, then rationalized assuming an equilibrium model including the species $\mathrm{H}_{3} \mathrm{~A}, \mathrm{H}_{2} \mathrm{~A}, \mathrm{~A}, \mathrm{BH}, \mathrm{B}, \mathrm{M}(\mathrm{OH}), \mathrm{M}(\mathrm{OH})_{2}, \mathrm{M}(\mathrm{A}), \mathrm{MA}(\mathrm{OH}), \mathrm{M}(\mathrm{B}), \mathrm{M}(\mathrm{A})(\mathrm{B}), \mathrm{M}_{2}(\mathrm{~A})_{2}(\mathrm{~B})$, $\mathrm{M}_{2}(\mathrm{~A})_{2}(\mathrm{~B}-\mathrm{H}), \mathrm{M}^{1} \mathrm{M}^{2}(\mathrm{~A})_{2}(\mathrm{~B})$ and $\mathrm{M}^{1} \mathrm{M}^{2}(\mathrm{~A})_{2}(\mathrm{~B}-\mathrm{H})$ (where the charges of the species have been ignored for the sake of simplicity) (A = L-cysteine, L-threonine, salicylglycine, salicylvaline and $\mathrm{BH}=$ imidazole). Evidence of the deprotonation of $\mathrm{BH}$ ligand is available at alkaline $p \mathrm{H} . \mathrm{N}_{1} \mathrm{H}$ deprotonation of the bidentate coordinated imidazole ligand in the binuclear species at $p \mathrm{H}>7.0$ is evident from spectral measurements. Stability constants of binary $\mathrm{M}(\mathrm{A}), \mathrm{M}(\mathrm{B})$ and ternary $\mathrm{M}(\mathrm{A})(\mathrm{B})$ complexes follow the Irving-Williams order.
\end{abstract}

Keywords. Homo/hetero-binuclear complexes; imidazole; metal(II); equilibrium study.

\section{Introduction}

Imidazole as a ligand plays an important role in biological systems, since the imidazole moiety of the histidyl residue in a large number of metalloproteins forms all or part of the binding site of many transition metal ions ${ }^{1-3}$. The imidazolate anion is known to act as a bridging ligand in certain metalloenzymes, for example, in bovine superoxide dismutase ${ }^{4,5}$ bridge formation takes place between $\mathrm{Cu}^{2+}$ and $\mathrm{Zn}^{2+}(\mathrm{Cu}-\mathrm{B}-\mathrm{Zn})$. Only a few studies have been reported ${ }^{6,7}$ on the aqueous coordination chemistry of imidazolate bridged complexes. Recently we reported ${ }^{8-10}$ some solution equilibrium studies of imidazolate bridged complexes with $\mathrm{Cu}^{2+}, \mathrm{Ni}^{2+}$ and $\mathrm{Zn}^{2+}$. The study is now extended by taking potentially tridentate ligands, viz. L-cysteine, L-threonine, salicylglycinate and salicylvalinate, three metal ions $\left(\mathrm{Cu}^{2+}, \mathrm{Ni}^{2+}\right.$ and $\left.\mathrm{Zn}^{2+}\right)$ and imidazole. The aqueous coordination chemistry of simple imidazolate bridged metal complexes is explored using $p \mathrm{H}$-potentiometric and $\mathrm{UV} / \mathrm{V}$ is spectroscopic techniques.

\footnotetext{
*For correspondence
} 


\section{Experimental}

\subsection{Materials}

L-Cysteine, L-threonine (s.d. Fine Chem.), imidazole (s.d. Fine Chem.) and copper perchlorate hexahydrate (Aldrich) were used as such. All other chemicals were of AR grade. Standard solution were prepared by using double-distilled $\mathrm{CO}_{2}$-free water and stored in the refrigerator.

\section{2 pH-metric studies}

$p \mathrm{H}$-measurements were made on a Systronics $p \mathrm{H}$-meter-235.

The following solutions were prepared in a total volume of $50 \mathrm{ml}$ for $p \mathrm{H}$-metric titrations.

(i) $\mathrm{HClO}_{4}(0.03 \mathrm{M})+\mathrm{NaClO}_{4}(0 \cdot 1 \mathrm{M})$.

(ii) $\mathrm{HClO}_{4}(0.03 \mathrm{M})+\mathrm{A}(0.003 \mathrm{M})+\mathrm{NaClO}_{4}(0.1 \mathrm{M})$.

(iii) $\mathrm{HClO}_{4}(0.03 \mathrm{M})+\mathrm{B}(0.003 \mathrm{M})+\mathrm{NaClO}_{4}(0 \cdot 1 \mathrm{M})$.

(iv) $\mathrm{HClO}_{4}(0.03 \mathrm{M})+\mathrm{M}(\mathrm{II})\left(\mathrm{ClO}_{4}\right)_{2}(0.003 \mathrm{M})+\mathrm{A}(0.003 \mathrm{M})+\mathrm{NaClO}_{4}(0.1 \mathrm{M})$.

(v) $\mathrm{HClO}_{4}(0.03 \mathrm{M})+\mathrm{M}(\mathrm{II})\left(\mathrm{ClO}_{4}\right)_{2}(0.003 \mathrm{M})+\mathrm{B}(0.003 \mathrm{M})+\mathrm{NaClO}_{4}(0.1 \mathrm{M})$.

(vi) $\mathrm{HClO}_{4}(0.03 \mathrm{M})+\mathrm{M}(\mathrm{II})\left(\mathrm{ClO}_{4}\right)_{2}(0.003 \mathrm{M})+\mathrm{A}(0.003 \mathrm{M})+\mathrm{B}(0.003 \mathrm{M})+$ $\mathrm{NaClO}_{4}(0 \cdot 1 \mathrm{M})$.

(vii) $\mathrm{HClO}_{4}(0.03 \mathrm{M})+\mathrm{M}(\mathrm{II})\left(\mathrm{ClO}_{4}\right)_{2}(0.006 \mathrm{M})+\mathrm{A}(0.006 \mathrm{M})+\mathrm{B}(0.003 \mathrm{M})+$ $\mathrm{NaClO}_{4}(0 \cdot 1 \mathrm{M})$.

(viii) $\mathrm{HClO}_{4}(0.03 \mathrm{M})+\mathrm{M}^{1}(\mathrm{II})\left(\mathrm{ClO}_{4}\right)_{2}(0.003 \mathrm{M})+\mathrm{M}^{2}(\mathrm{II})\left(\mathrm{ClO}_{4}\right)_{2}(0.003 \mathrm{M})+\mathrm{A}$ $(0.006 \mathrm{M})+\mathrm{B}(0.003 \mathrm{M})+\mathrm{NaClO}_{4}(0 \cdot 1 \mathrm{M})$.

Each of the above samples set was titrated against $1.0 \mathrm{M} \mathrm{NaOH}$. The procedure followed for the $p \mathrm{H}$-metric measurements was as described in the literature ${ }^{11-18}$. The formation constants were evaluated using the SCOGS computer programme ${ }^{19}$.

\section{$2.3 \quad U V$-visible studies}

Aqueous solutions examined by UV-visible spectroscopy were prepared as described above. The optical absorption spectra were recorded on a Systronics UV-visible spectrophotometer-117 with $1 \mathrm{~cm}$ quartz cell in aqueous solution at appropriate $p \mathrm{H}$ values. The extinction coefficients for complexes were also calculated from the solution concentration at the respective absorbance maxima.

\section{Results and discussion}

\subsection{Proton-ligand formation constants}

Both the aminoacids used are tridentate. The L-cysteine has three coordination sites viz., $-\mathrm{COOH},-\mathrm{SH}$ and $-\mathrm{NH}_{2}$, the L-threonine system has $-\mathrm{COOH},-\mathrm{NH}_{2},-\mathrm{OH}$ and salgly/salval have $-\mathrm{COOH},-\mathrm{OH}$ and $>\mathrm{NH}$ groups. The protonation constants for the aminoacids, Sciff bases and imidazole are presented in table 1 . These $p K$ values correspond to the earlier reported ${ }^{11-18}$ values. The overall stability constant values are 
reported in tables 1-5 and some representative distribution curves are shown in figures 1 and 2.

\subsection{Metal-ligand formation constants of binary (1:1) systems}

The stabilities of different types of species in complexation equilibria depend upon the experimental conditions used. The complexation equilibria of the binary $\left(\mathrm{M}^{2+}: \mathrm{A}\right)$ systems have shown the presence of the following species by stoichiometry: $\mathrm{H}_{3} \mathrm{~A}, \mathrm{H}_{2} \mathrm{~A}$, $\mathrm{HA}, \mathrm{A}, \mathrm{M}^{2+}, \mathrm{M}(\mathrm{OH}), \mathrm{M}(\mathrm{OH})_{2},(\mathrm{MA}), \mathrm{MA}(\mathrm{OH})$. Similarly in the $\mathrm{M}^{2+}: \mathrm{BH}(1: 1)$ binary system the species present are $\mathrm{BH}, \mathrm{B}, \mathrm{M}(\mathrm{OH}), \mathrm{M}(\mathrm{OH})_{2}, \mathrm{M}(\mathrm{B})$ and $\mathrm{M}(\mathrm{B})(\mathrm{OH})$. Among these binary simple complexes, the stability of hydroxy species have also been considered in calculating the stability constants, since the buffer regions corresponding to metal ligand complex formation equilibria overlap with the hydrolytic equilibria of the $\mathrm{M}^{2+}$ (aq.) ions. Ternary hydroxo complexes $\mathrm{MA}(\mathrm{OH})$ and $\mathrm{M}(\mathrm{B})(\mathrm{OH})$ occur with all the three $\mathrm{M}^{2+}$ ions $(\mathrm{M}=\mathrm{Cu}, \mathrm{Ni}$ and $\mathrm{Zn})$; however, the abundance of binary hydroxo species, $\mathrm{M}(\mathrm{OH})$ and $\mathrm{M}(\mathrm{OH})_{2}$ is relatively higher with $\mathrm{Zn}^{2+}$. The $\log \beta_{\mathrm{MA}}$ and $\log \beta_{\mathrm{MB}}$ values obtained in the present work (table 3 ) correspond to the tridentate and monodentate binding of ligands respectively.

\subsection{Metal-ligand formation constants of ternary (1:1:1/2:2:1) systems}

Earlier workers ${ }^{18,20-25}$ have studied various types of mononuclear ternary complexes particularly with $\mathrm{Zn}$ (II) metal ion under different conditions. Ternary species detected are $\mathrm{Zn}(\mathrm{A})(\mathrm{BH})$ and $\mathrm{Zn}(\mathrm{A})(\mathrm{B})$ in the $\mathrm{Zn}(\mathrm{II})-\mathrm{Cys}(\mathrm{A})-\mathrm{BH}$ system. The ternary species obtained in the present study differ from the ones reported above. Thus, in the title system with $(1: 1: 1)$ stoichiometry for $\mathrm{M}(\mathrm{A})(\mathrm{B})$ and $\mathrm{M}(\mathrm{A})(\mathrm{B})(\mathrm{OH})$, the binary species discussed in $\$ 3.2$ could also be detected, and the stability constants obtained for the common ternary species are consistent with those obtained by earlier workers ${ }^{18}$ (table 4).

Table 1. Stability constants of ligands at $25 \pm 1^{\circ} \mathrm{C}$ and $I=0 \cdot 1 \mathrm{M} \mathrm{NaClO}_{4}$ (standard deviations are \pm 0.02 in $\log$ units).

\begin{tabular}{lcccc}
\hline $\mathrm{H}^{+}$complex & $\begin{array}{c}\text { L-Cysteine } \\
\log \beta_{00 \mathrm{rst}}\end{array}$ & $\begin{array}{c}\text { L-Threonine } \\
\log \beta_{00 \mathrm{rst}}\end{array}$ & $\begin{array}{c}\text { SalGly } \\
\log \beta_{00 \mathrm{rst}}\end{array}$ & $\begin{array}{c}\text { SalVal } \\
\log \beta_{00 \mathrm{rst}}\end{array}$ \\
\hline $\mathrm{H}_{3} \mathrm{~A}$ & $20 \cdot 82(19 \cdot 93)^{*}$ & - & & \\
$\mathrm{H}_{2} \mathrm{~A}$ & $18 \cdot 73(18 \cdot 53)^{*}$ & $11 \cdot 51$ & $11 \cdot 68$ & $11 \cdot 73$ \\
$\mathrm{HA}$ & $10 \cdot 36(10 \cdot 31)^{*}$ & $9 \cdot 18$ & $8 \cdot 24$ & $8 \cdot 29$ \\
$\mathrm{BH}$ & $7 \cdot 10$ & $7 \cdot 10$ & $7 \cdot 10$ & $7 \cdot 10$ \\
\hline
\end{tabular}

*Ref. 18

Table 2. Hydrolytic constants $\left(\log \beta_{\mathrm{p} 000 \mathrm{t}}\right)$ of $\mathrm{M}^{2+}$ ions.

\begin{tabular}{lrrr}
\hline Complex & $\mathrm{Ni}(\mathrm{II})$ & $\mathrm{Cu}(\mathrm{II})$ & $\mathrm{Zn}(\mathrm{II})$ \\
\hline $\mathrm{M}(\mathrm{OH})^{+}$ & $-8 \cdot 10$ & -7.29 & $-7 \cdot 89$ \\
$\mathrm{M}(\mathrm{OH})_{2}$ & -16.87 & $-13 \cdot 10$ & -14.92 \\
\hline
\end{tabular}

*Ref. 18 


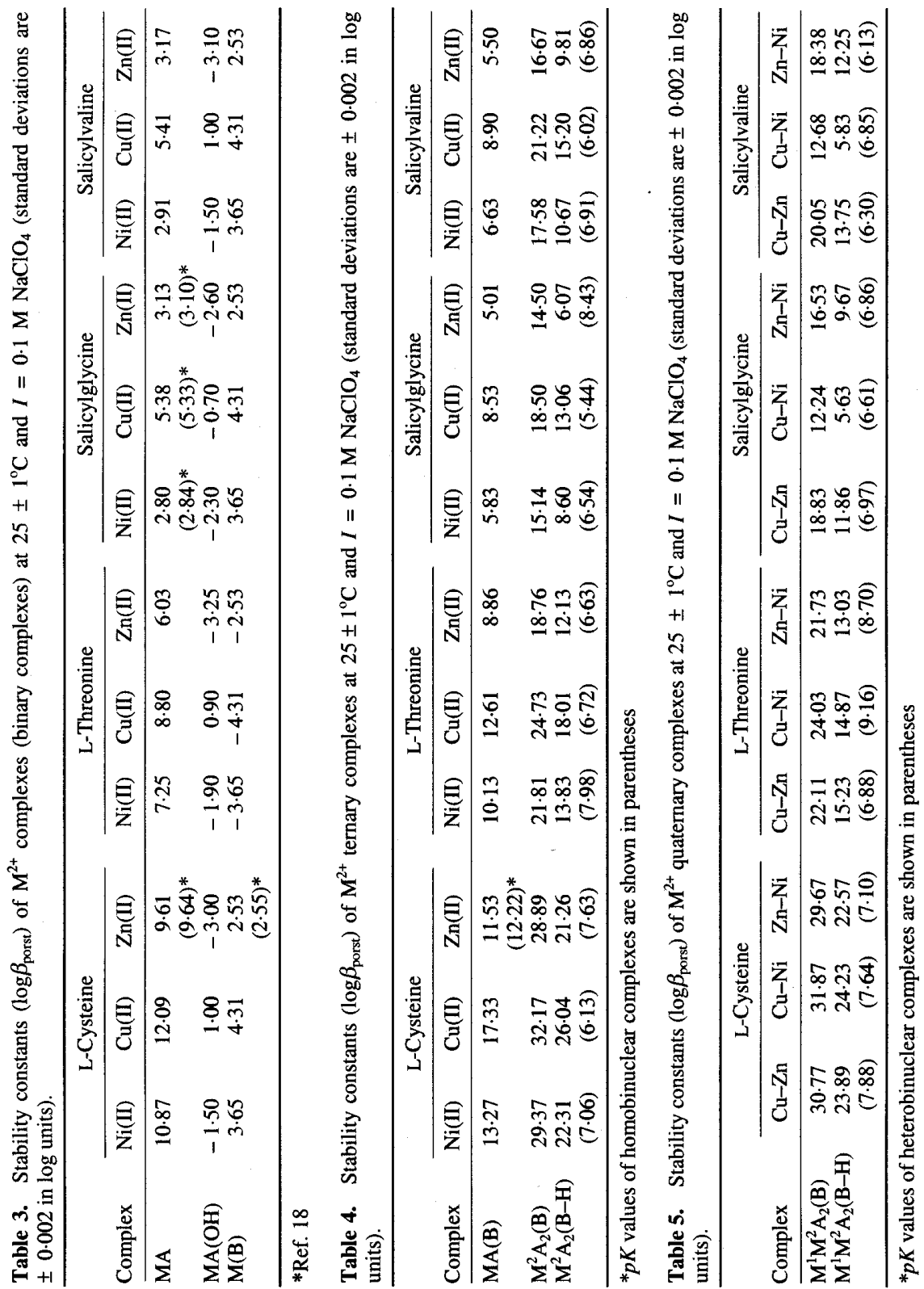


The $\mathrm{M}^{2+}: \mathrm{A}: \mathrm{BH}(2: 2: 1)$ system in the $p \mathrm{H}$ range $~ 5-6.5$ suggests the formation of homo-binuclear $\mathrm{M}_{2}(\mathrm{~A})_{2}(\mathrm{~B})$ complexes. The formation of homo-binuclear complexes takes place according to the following equilibrium:

$$
2 \mathrm{Cu}(\mathrm{A})+\mathrm{BH} \rightleftharpoons \mathrm{Cu}_{2}(\mathrm{~A})_{2}(\mathrm{~B})+\mathrm{H}^{+}
$$

Binuclear complexes with the other two metal ions are, however, found to be formed according to the equilibria:

$$
\begin{aligned}
& \mathrm{M}(\mathrm{II})+\mathrm{HA}+\mathrm{BH} \rightleftharpoons \mathrm{MA}(\mathrm{B})+2 \mathrm{H}^{+}, \\
& 2 \mathrm{M}(\mathrm{II})+2 \mathrm{HA}+\mathrm{BH} \rightleftharpoons \mathrm{M}_{2}(\mathrm{~A})_{2}(\mathrm{~B})+3 \mathrm{H}^{+} .
\end{aligned}
$$

Figure 1 shows the species distribution curves of homo-binuclear complexes.

\subsection{Quaternary (1:1:2:1) systems}

Species distribution curves for the quaternary systems are presented in figure 2. The titration curves of all present quaternary systems are similar to one another. The titration curves of various quaternary systems show only one equivalent point $(p \mathrm{H} \sim 7.0)$ which is attributed to the formation of quaternary species according to the following general equation,

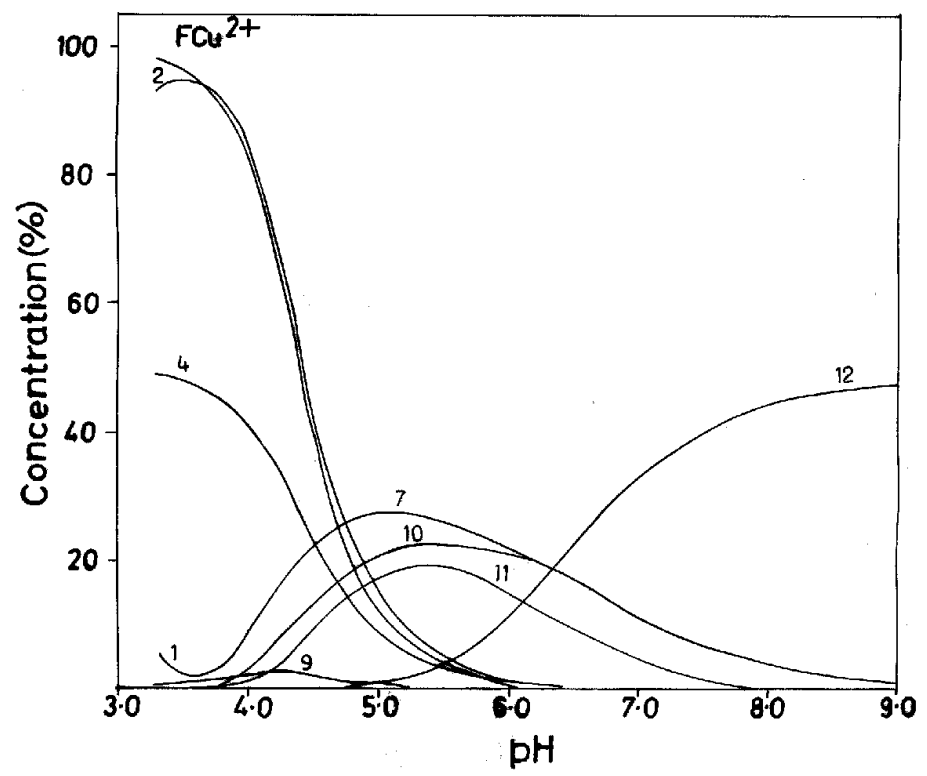

Figure 1. Species distribution curves of $2: 2: 1, \mathrm{Cu}^{2+}: \mathrm{AH}: \mathrm{BH}(\mathrm{A}=\mathrm{L}-\mathrm{cysteine})$ system: (1) $\mathrm{H}_{3} \mathrm{~A}$ (2) $\mathrm{H}_{2} \mathrm{~A}$, (3) $\mathrm{HA}$, (4) $\mathrm{BH}$, (5) $\mathrm{Cu}(\mathrm{OH})$, (6) $\mathrm{Cu}(\mathrm{OH})_{2}$, (7) $\mathrm{CuA}$, (8) $\mathrm{Cu}(\mathrm{A})(\mathrm{OH}),(9) \mathrm{Cu}(\mathrm{B}),(10) \mathrm{Cu}(\mathrm{A})(\mathrm{B}),(11) \mathrm{Cu}_{2}(\mathrm{~A})_{2}(\mathrm{~B})$ and (12) $\mathrm{Cu}_{2}(\mathrm{~A})_{2}(\mathrm{~B}-\mathrm{H})$. 


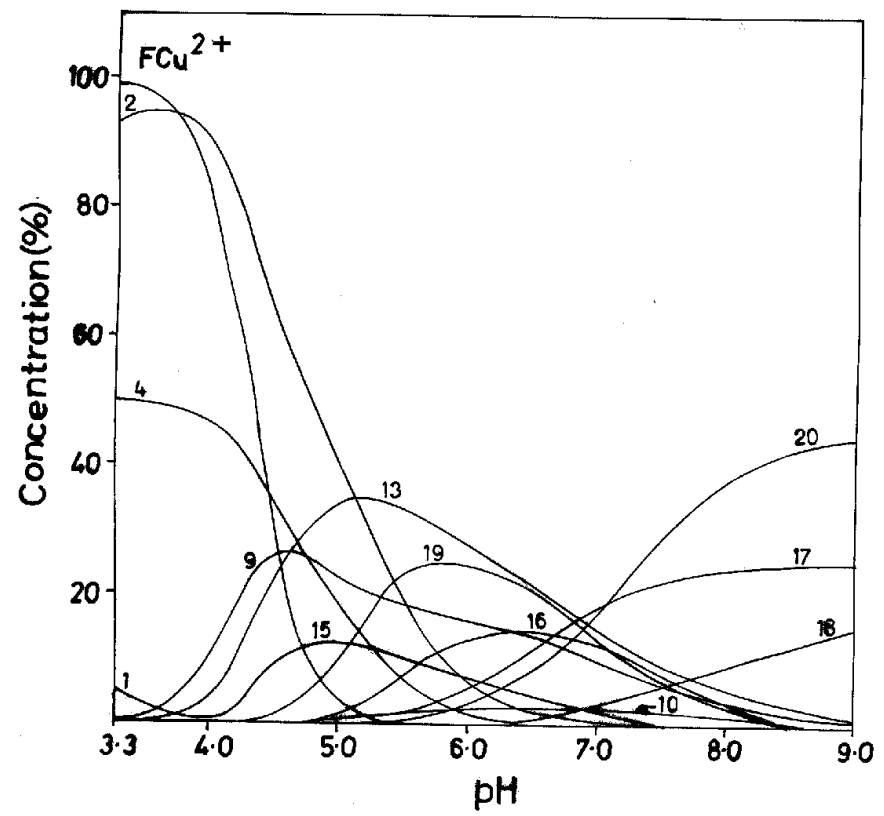

Figure 2. Species distribution curves of $1: 1: 2: 1, \mathrm{Cu}^{2+}: \mathrm{Zn}^{2+}: \mathrm{AH}: \mathrm{BH}(\mathrm{A}=\mathrm{L}-$ cysteine) system: (1) $\mathrm{H}_{3} \mathrm{~A}$, (2) $\mathrm{H}_{2} \mathrm{~A}$, (3) $\mathrm{HA}$, (4) $\mathrm{BH}$, (5) $\mathrm{Cu}(\mathrm{OH}),(6) \mathrm{Cu}(\mathrm{OH})_{2}$, (7) $\mathrm{Zn}(\mathrm{OH}),(8) \mathrm{Zn}(\mathrm{OH})_{2}$, (9) $\mathrm{CuA},(10) \mathrm{Zn}(\mathrm{A}),(11) \mathrm{Cu}(\mathrm{A})(\mathrm{OH}),(12) \mathrm{Zn}(\mathrm{A})(\mathrm{OH}),(13)$ $\mathrm{Cu}(\mathrm{A})(\mathrm{B}),(14) \mathrm{Zn}(\mathrm{A})(\mathrm{B}),(15) \mathrm{Cu}_{2}(\mathrm{~A})_{2}(\mathrm{~B}),(16) \mathrm{Zn}_{2}(\mathrm{~A})_{2}(\mathrm{~B}),(17) \mathrm{Cu}_{2}(\mathrm{~A})_{2}(\mathrm{~B}-\mathrm{H}),(18)$ $\mathrm{Zn}_{2}(\mathrm{~A})_{2}(\mathrm{~B}-\mathrm{H}),(19) \mathrm{CuZn}(\mathrm{A})_{2}(\mathrm{~B})$ and $(20) \mathrm{CuZn}(\mathrm{A})_{2}(\mathrm{~B}-\mathrm{H})$.

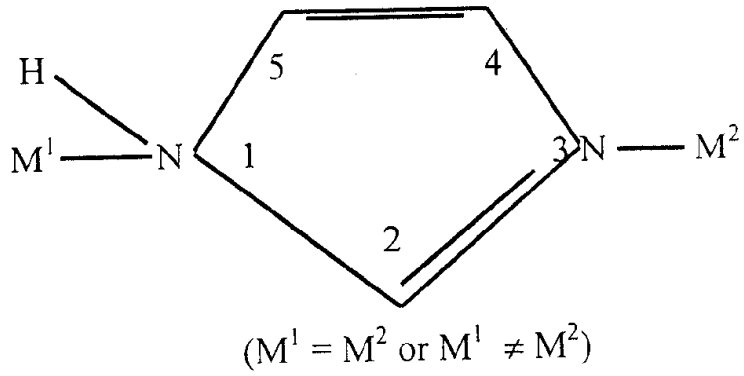

Chart 1.

$$
\mathrm{M}^{1}(\mathrm{~A})+\mathrm{BH}+\mathrm{M}^{2} \mathrm{~A} \rightleftharpoons \mathrm{M}^{1} \mathrm{M}^{2}(\mathrm{~A})_{2}(\mathrm{~B})
$$

All ligands used except imidazole provide $\left(\mathrm{S}, \mathrm{N}, \mathrm{O}^{-}\right)$terdentate chelation to the metal ion $\mathrm{M}(\mathrm{II})$ ions in $\mathrm{M}(\mathrm{A})$ and $\mathrm{M}(\mathrm{A})(\mathrm{B})$ complexes. The imidazole in the ternary $(1: 1: 1)$ complexes functions as monodentate ligand coordinating through pyridine nitrogen ${ }^{26}$. Simultaneous occurance of mononuclear ternary complexes $\mathrm{M}(\mathrm{A})(\mathrm{B})$ and homo/heterobinuclear ternary complex systems suggest $\left(\mathrm{N}_{1}, \mathrm{~N}_{3}\right)$ bridging bidentate coordination by the imidazole ligand in binuclear complexes (chart 1). 


\subsection{Deprotonated systems}

The quaternary titration curves show the second buffer zone at $p \mathrm{H} \sim 8.0$ which is attributed to the formation of a deprotonated species. The possible site for deprotonation may be the $\mathrm{N}_{1} \mathrm{H}$ of the bridging ligand according to the following general equilibrium,

$$
\mathrm{M}_{2}(\mathrm{~A})_{2}(\mathrm{~B}) \rightleftharpoons \mathrm{M}_{2}(\mathrm{~A})_{2}(\mathrm{~B}-\mathrm{H})+\mathrm{H}^{+}
$$

The deprotonation constants were also evaluated and are presented in tables 4 and 5 . These deprotonation constants of bridging bidentate coordinated imidazole are found to be lower for $\mathrm{Cu}^{2+}$ and $\mathrm{Ni}^{2+}$ ions presumbly because of stronger $\mathrm{M}(d \pi) \rightarrow \mathrm{B}(\pi)$ interaction, due to which the electron density on the imidazole ligand is increased, and this disfavours the release of the $\mathrm{N}_{1} \mathrm{H}$ proton. Such $\pi$-bonding is, of course, absent in the corresponding $\mathrm{Zn}^{2+}$ complexes. Consequently, coordinated imidazole in the homobinuclear $\mathrm{Zn}^{2+}$ complex $(\mathrm{Zn})_{2}(\mathrm{~A})_{2} \mathrm{~B}$ shows higher acidity relative to complexes with $\mathrm{Ni}^{2+}$

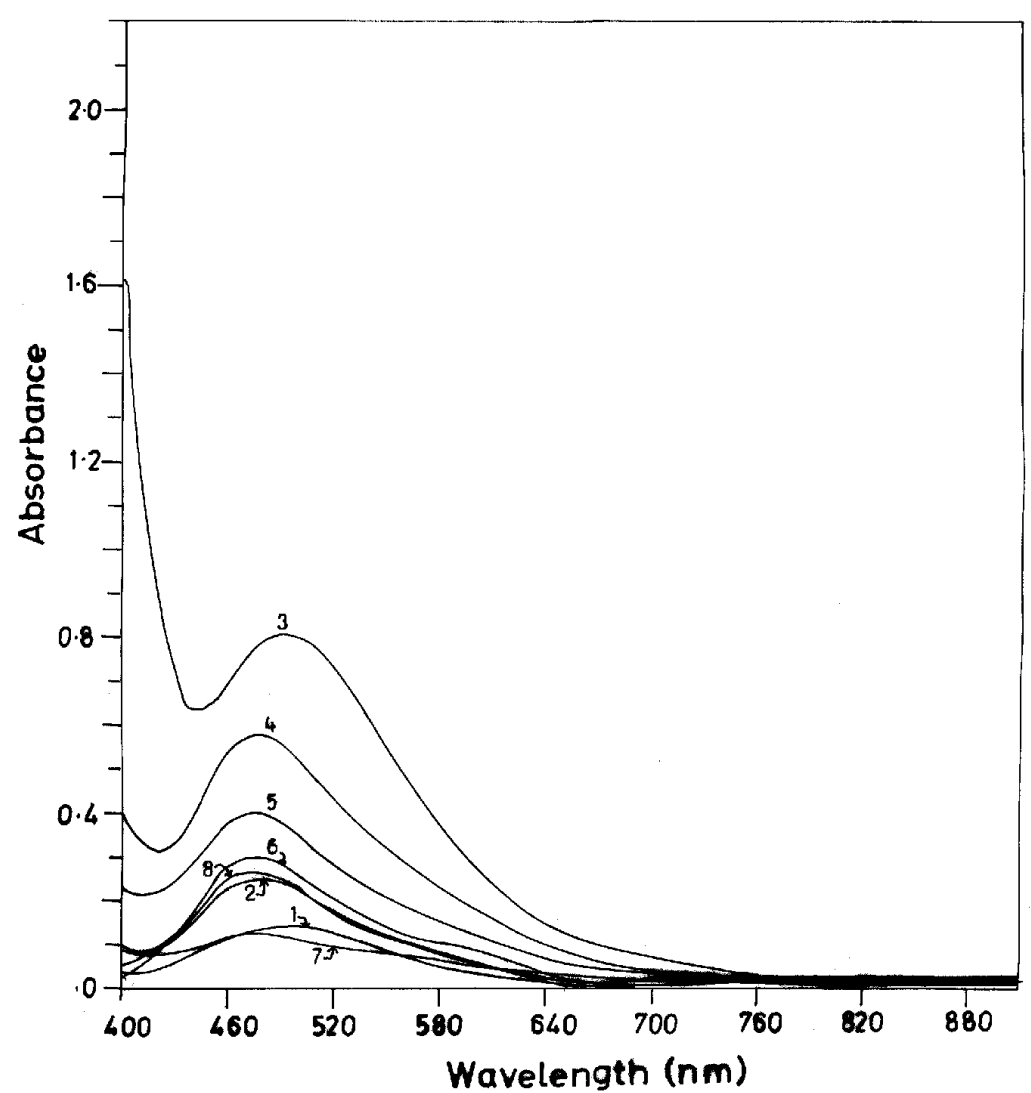

Figure 3. Visible spectra for different complexes containing $\mathrm{Ni}^{\mathrm{II}}$, (1) $\mathrm{Ni}(\mathrm{A}), p \mathrm{H} 6 \cdot 0$, (2) $\mathrm{Ni}(\mathrm{A})(\mathrm{B}), p \mathrm{H} 7 \cdot 0,(3) \mathrm{Ni}_{2}(\mathrm{~A})_{2}(\mathrm{~B}), p \mathrm{H} 6 \cdot 5,(4) \mathrm{Ni}_{2}(\mathrm{~A})_{2}(\mathrm{~B}-\mathrm{H}), p \mathrm{H} 8 \cdot 5,(5) \mathrm{CuNi}$ $(\mathrm{A})_{2}(\mathrm{~B}), p \mathrm{H} 6 \cdot 5,(6) \mathrm{CuNi}(\mathrm{A})_{2}(\mathrm{~B}-\mathrm{H}), p \mathrm{H} 8 \cdot 5$, (7) $\mathrm{NiZn}(\mathrm{A})_{2}(\mathrm{~B}), p \mathrm{H} 6.5$ and (8) $\mathrm{NiZn}(\mathrm{A})_{2}(\mathrm{~B}-\mathrm{H}), p \mathrm{H} 8.5$. 
and $\mathrm{Cu}^{2+}$. The imidazole anion, $(\mathrm{B}-\mathrm{H})^{-}$, may provide $\left(\mathrm{N}_{1}, \mathrm{~N}_{3}\right)$ bridging bidentate coordination in the $\mathrm{M}_{2}(\mathrm{~A})_{2}(\mathrm{~B}-\mathrm{H})$ and $\mathrm{M}^{1} \mathrm{M}^{2}(\mathrm{~B}-\mathrm{H})$ complex, exactly in the same manner that the active site of the imidazole residue of histidine-61 at the active site of bovine superoxide dismutase coordinates one $\mathrm{Cu}^{2+}$ ion and one $\mathrm{Zn}^{2+}$ ion ${ }^{27}$.

\subsection{Formation constants with respect to metal ion}

Stability constants of the binary $\mathrm{M}(\mathrm{A}), \mathrm{M}(\mathrm{B})$ and ternary $\mathrm{M}(\mathrm{A})(\mathrm{B})$ complex follow the Irving-Williams order ${ }^{28,29}$. In general, stability constants of the binuclear complexes are in the order: $\mathrm{CuCu}>\mathrm{CuNi}>\mathrm{CuZn}>\mathrm{ZnNi}>\mathrm{NiNi}>\mathrm{ZnZn}$. Slightly higher stability of the NiZn hetero-binuclear complex over the corresponding NiNi and $\mathrm{ZnZn}$ complexes is observed. The single $\mathrm{Ni}(d \pi) \rightarrow \mathrm{B}(\pi)$ back-bonding in the $\mathrm{NiZn}(\mathrm{A})_{2}(\mathrm{~B})$ complex adds to its stability, whereas two opposing $\mathrm{Ni}(d \pi) \rightarrow \mathrm{B}(\pi)$ bonds in the $\mathrm{Ni}_{2}(\mathrm{~A})_{2}(\mathrm{~B})$ complex possibly mutually weaken each other. As a result, the stability of the $\mathrm{Ni}-\mathrm{Ni}$ complex is slightly lower than that of the $\mathrm{Ni}-\mathrm{Zn}$ complex.

\subsection{Absorption spectra}

The $p \mathrm{H}$-dependence visible absorption spectra are recorded for different nickel(II) binary, ternary and quaternary systems with L-cysteine. The spectra are shown in figure 3 and visible absorption data are presented in tables 6 and 7. The nickel(II)-L-cysteine (1:1) complex shows $\lambda_{\max }$ at $492 \mathrm{~nm}$ whereas the nickel(II)-L-cysteine-B (1:1:1) systems shows $\lambda_{\max }$ at $476 \mathrm{~nm}$. This decrease in $\lambda_{\max }$ is due to the fourth ligand (imidazole). This

Table 6. Spectrophotometirc data for nickel(II) complexes with L-cysteine, Lthreonine and imidazole.

\begin{tabular}{|c|c|c|c|c|}
\hline Composition & Complex & $p \mathrm{H}$ & $\lambda_{\max }(\mathrm{nm})$ & $\begin{array}{c}\varepsilon \\
\left(\mathrm{dm}^{3} \mathrm{~mol}^{-1} \mathrm{~cm}^{-1}\right)\end{array}$ \\
\hline \multicolumn{5}{|l|}{ (A) Complexes with L-cysteine } \\
\hline $\mathrm{Ni}^{2+}: \mathrm{AH}(1: 1)$ & $\mathrm{Ni}(\mathrm{A})$ & $6 \cdot 0$ & 492 & 47 \\
\hline $\mathrm{Ni}^{2+}: \mathrm{AH}: \mathrm{BH}(1: 1: 1)$ & $\mathrm{Ni}(\mathrm{A})(\mathrm{B})$ & $7 \cdot 0$ & 476 & 84 \\
\hline $\mathrm{Ni}^{2+}: \mathrm{AH}: \mathrm{BH}(2: 2: 1)$ & $\mathrm{Ni}_{2}(\mathrm{~A})_{2}(\mathrm{~B})$ & $6 \cdot 5$ & 496 & 179 \\
\hline $\mathrm{NI}^{2+}: \mathrm{AH}: \mathrm{BH}(2: 2: 1)$ & $\mathrm{Ni}_{2}(\mathrm{~A})_{2}(\mathrm{~B}-\mathrm{H})$ & $8 \cdot 5$ & 480 & 191 \\
\hline $\mathrm{Cu}^{2+}: \mathrm{Ni}^{2+}: \mathrm{AH}: \mathrm{BH}(1: 1: 2: 1)$ & $\mathrm{CuNi}(\mathrm{A})_{2}(\mathrm{~B})$ & $6 \cdot 5$ & 476 & 40 \\
\hline $\mathrm{Cu}^{2+}: \mathrm{Ni}^{2+}: \mathrm{AH}: \mathrm{BH}(1: 1: 2: 1)$ & $\mathrm{CuNi}(\mathrm{A})_{2}(\mathrm{~B}-\mathrm{H})$ & $8 \cdot 5$ & 476 & 86 \\
\hline $\mathrm{Ni}^{2+}: \mathrm{Zn}^{2+}: \mathrm{AH}: \mathrm{BH}(1: 1: 2: 1)$ & $\mathrm{NiZn}(\mathrm{A})_{2}(\mathrm{~B})$ & $6 \cdot 5$ & 478 & 133 \\
\hline $\mathrm{Ni}^{2+}: \mathrm{Zn}^{2+}: \mathrm{AH}: \mathrm{BH}(1: 1: 2: 1)$ & $\mathrm{NiZn}(\mathrm{A})_{2}(\mathrm{~B}-\mathrm{H})$ & $8 \cdot 5$ & 476 & 99 \\
\hline \multicolumn{5}{|c|}{ (B) Complexes with L-threonine } \\
\hline $\mathrm{Cu}^{2+}: \mathrm{AH}(1: 1)$ & $\mathrm{Cu}(\mathrm{A})$ & $6 \cdot 0$ & 735 & 16 \\
\hline $\mathrm{Cu}^{2+}: \mathrm{AH}: \mathrm{BH}(1: 1: 1)$ & $\mathrm{Cu}(\mathrm{A})(\mathrm{B})$ & $7 \cdot 0$ & 684 & 36 \\
\hline $\mathrm{Cu}^{2+}: \mathrm{AH}: \mathrm{BH}(2: 2: 1)$ & $\mathrm{Cu}_{2}(\mathrm{~A})_{2}(\mathrm{~B})$ & $6 \cdot 5$ & 695 & 60 \\
\hline $\mathrm{Cu}^{2+}: \mathrm{AH}: \mathrm{BH}(2: 2: 1)$ & $\mathrm{Cu}_{2}(\mathrm{~A})_{2}(\mathrm{~B}-\mathrm{H})$ & $8 \cdot 5$ & 642 & 93 \\
\hline $\mathrm{Cu}^{2+}: \mathrm{Zn}^{2+}: \mathrm{AH}: \mathrm{BH}(1: 1: 2: 1)$ & $\mathrm{CuZn}(\mathrm{A})_{2}(\mathrm{~B})$ & $6 \cdot 5$ & 637 & 50 \\
\hline $\mathrm{Cu}^{2+}: \mathrm{Zn}^{2+}: \mathrm{AH}: \mathrm{BH}(1: 1: 2: 1)$ & $\mathrm{CuZn}(\mathrm{A})_{2}(\mathrm{~B}-\mathrm{H})$ & $8 \cdot 5$ & 640 & 76 \\
\hline $\mathrm{Cu}^{2+}: \mathrm{Ni}^{2+}: \mathrm{AH}: \mathrm{BH}(1: 1: 2: 1)$ & $\mathrm{CuNi}(\mathrm{A})_{2}(\mathrm{~B})$ & 6.5 & 644 & 50 \\
\hline $\mathrm{Cu}^{2+}: \mathrm{Ni}^{2+}: \mathrm{AH}: \mathrm{BH}(1: 1: 2: 1)$ & $\mathrm{CuNi}(\mathrm{A})_{2}(\mathrm{~B}-\mathrm{H})$ & $8 \cdot 5$ & 637 & 59 \\
\hline
\end{tabular}


Table 7. Spectrometric data for copper(II) complexes with salicylglycine, salicylvaline and imidazole.

\begin{tabular}{|c|c|c|c|c|c|c|}
\hline \multirow[b]{2}{*}{ Composition } & \multirow[b]{2}{*}{ Complex } & \multirow[b]{2}{*}{$p \mathrm{H}$} & \multicolumn{2}{|c|}{ Salicylglycine } & \multicolumn{2}{|c|}{ Salicylvaline } \\
\hline & & & $\begin{array}{l}\lambda_{\max } \\
(\mathrm{nm})\end{array}$ & $\begin{array}{c}\varepsilon\left(\mathrm{dm}^{3}\right. \\
\left.\mathrm{mol}^{-1} \mathrm{~cm}^{-1}\right)\end{array}$ & $\begin{array}{l}\lambda_{\max } \\
(\mathrm{nm})\end{array}$ & $\begin{array}{c}\varepsilon\left(\mathrm{dm}^{3}\right. \\
\left.\mathrm{mol}^{-1} \mathrm{~cm}^{-1}\right)\end{array}$ \\
\hline $\mathrm{Cu}^{2+}: \mathrm{AH}(1: 1)$ & $\mathrm{Cu}(\mathrm{A})$ & 6.5 & 626 & 37 & 623 & 72 \\
\hline $\mathrm{Cu}^{2+}: \mathrm{AH}: \mathrm{BH}(1: 1: 1)$ & $\mathrm{Cu}(\mathrm{A})(\mathrm{B})$ & 7.0 & 638 & 66 & 627 & 87 \\
\hline $\mathrm{Cu}^{2+}: \mathrm{AH}: \mathrm{BH}(2: 2: 1)$ & $\mathrm{Cu}_{2}(\mathrm{~A})_{2}(\mathrm{~B})$ & 7.5 & 630 & 78 & 648 & 143 \\
\hline $\mathrm{Cu}^{2+}: \mathrm{AH}: \mathrm{BH}(2: 2: 1)$ & $\mathrm{Cu}_{2}(\mathrm{~A})_{2}(\mathrm{~B}-\mathrm{H})$ & 8.5 & 630 & 74 & 637 & 158 \\
\hline $\mathrm{Cu}^{2+}: \mathrm{Zn}^{2+}: \mathrm{AH}: \mathrm{BH}(1: 1: 2: 1)$ & $\mathrm{CuZn}(\mathrm{A})_{2}(\mathrm{~B})$ & 7.5 & 627 & 56 & 634 & 66 \\
\hline $\mathrm{Cu}^{2+}: \mathrm{Zn}^{2+}: \mathrm{AH}: \mathrm{BH}(1: 1: 2: 1)$ & $\mathrm{CuZn}(\mathrm{A})_{2}(\mathrm{~B}-\mathrm{H})$ & 8.5 & 627 & 55 & 616 & 75 \\
\hline $\mathrm{Cu}^{2+}: \mathrm{Ni}^{2+}: \mathrm{AH}: \mathrm{BH}(1: 1: 2: 1)$ & $\mathrm{CuNi}(\mathrm{A})_{2}(\mathrm{~B})$ & 7.5 & 619 & 30 & 620 & 90 \\
\hline $\mathrm{Cu}^{2+}: \mathrm{Ni}^{2+}: \mathrm{AH}: \mathrm{BH}(1: 1: 2: 1)$ & $\mathrm{CuNi}(\mathrm{A})_{2}(\mathrm{~B}-\mathrm{H})$ & 8.5 & 619 & 30 & 620 & 106 \\
\hline
\end{tabular}

ligand exerts higher ligand fields than L-cysteine and also is attached in the equatorial position of nickel(II). As is known, however, the axial coordination in metal(II) complexes results in a blue shift of the electron absorption spectra ${ }^{30}$. The nickel(II) binuclear complex formed at $p \mathrm{H} 6.5$ shows $\lambda_{\max }$ at $496 \mathrm{~nm}$. The $\lambda_{\max }$ of this binuclear species is greater than that of mononuclear ternary complexes. The enhanced $\lambda_{\max }$ value due to the average ligand field exerted by the bridging imidazole ligand $(\mathrm{BH})$ on the nickel(II) ion in $\mathrm{Ni}_{2}(\mathrm{~A})_{2}$ (B) is definitely weaker than the field exerted by the same ligand (BH) when it is coordinates a single nickel(II) ion as monodentate ligand in the mononuclear ternary complex, $\mathrm{Ni}(\mathrm{A})(\mathrm{B})$. On raising the $p \mathrm{H}$ to 8.5 the observed $\lambda_{\max }$ value is $480 \mathrm{~nm}$. This decrease in $\lambda_{\max }$ is due to the $\mathrm{N}_{1} \mathrm{H}$ deprotonation of the bridging imidazole ligand $(\mathrm{BH})$ in the binuclear species $\mathrm{Ni}_{2}(\mathrm{~A})_{2}(\mathrm{~B}-\mathrm{H})$, that provides an additional electron to the bridging ligand $(\mathrm{BH})$. The resulting $(\mathrm{B}-\mathrm{H})$ anion in the deprotonated complex, $\mathrm{Ni}_{2}(\mathrm{~A})_{2}(\mathrm{~B}-\mathrm{H})$, obviously exerts a stronger ligand field than that exerted by the neutral ligand (BH). As a consequence, this deprotonated complex absorbs at slightly shorter wavelength. This is clearly evident from the blue shifts in absorption maxima by $\sim 15 \mathrm{~nm}$ on increasing the $p \mathrm{H}$ of the same binuclear system. Therefore our results suggest metal promoted deprotonation and also that coordination of the fourth ligand in the simple ternary nickel(II) system is at the equatorial position of the $\mathrm{Ni}(\mathrm{A}) \mathrm{B}$ species. $\mathrm{We}$ have also recorded the $p \mathrm{H}$-dependence visible absorption spectra for different copper(II) binary, ternary and quaternary systems using L-threonine salGly and salVal. Visible absorption data are presented in tables 6 and 7. The copper(II)-L-threonine (1:1) complex yields $\lambda_{\max }$ at $735 \mathrm{~nm}$ whereas the copper(II)-L-threonine-imH (1:1:1) system yields $\lambda_{\max }$ at $684 \mathrm{~nm}$. This decrease in $\lambda_{\max }$ is due to the fourth ligand (imidazole). The copper(II) binuclear complex formed as $p \mathrm{H} 6.5$ shows $\lambda_{\max }$ at $695 \mathrm{~nm}$. The $\lambda_{\max }$ of this binuclear species is greater than that of the mononuclear ternary complexes. On further raising the $p \mathrm{H}$ to 8.5 the obtained $\lambda_{\max }$ value is $642 \mathrm{~nm}$. This decrease in $\lambda_{\max }$ is due to the $\mathrm{N}_{1} \mathrm{H}$ deprotonatin of the bridging imidazole ligand (imH) in the binuclear species $\mathrm{Cu}_{2}(\mathrm{~A})_{2}(\mathrm{~B}-\mathrm{H})$ that provides an additional electron to the bridging ligand $(\mathrm{B}-\mathrm{H})$.

\section{Acknowledgement}

We thank the University Grants Commission (UGC), New Delhi for financial assistance. 


\section{References}

1. Anderson K K and Graslund A 1995 Adv. Inorg. Chem. 43359

2. Messerschmidt A 1993 Adv. Inorg. Chem. 40121

3. Mekee V 1993 Adv. Inorg. Chem. 41323

4. Palmer G, Babcock G T, Vickery L E 1996 Proc. Natl. Acad. Sci. USA 732206

5. Tweedle M F, Wilson L J, Garcia L-Iniguez, Babcock G T and Palmer G J 1978 Biol. Chem. 2538065

6. Mukherjee G N and Sahu H K 1998 J. Indian Chem. Soc. 75143

7. Mukherjee G N and Sahu H K 2000 J. Indian Chem. Soc. 77209

8. Patel R N, Shrivastava R P, Singh Nripendra and Pandeya K B 2000 Proc. Natl. Acad. Sci. India A70 133

9. Patel R N, Singh N, Shrivastava R P, Kumar S and Pandeya K B 2000 J. Mol. Liq. 89207

10. Patel R N, Shrivastava R P, Singh N, Kumar S and Pandeya K B 2001 Indian J. Chem. A40 361

11. Patel R N and Pandeya K B 1990 Indian J. Chem. A29 602

12. Patel R N and Pandeya K B 1991 Indian J. Chem. A30 193

13. Patel R N, Pandey H C, Pandeya K B and Mukherjee G N 1999 Indian J. Chem. A38 850

14. Patel R N, Pandey H C and Pandeya K B 1996 Bull. Electrochem. 12616

15. Patel R N, Pandey H C and Pandeya K B 1996 J. Electrochem. Soc. 45189

16. Patel R N, Gokhale P and Pandeya K B 1999 J. Indian Chem. Soc. 76475

17. Pessoa J C, Boas L F V and Gillard R D 1989 Polyhedron 81173

18. Nair M S, Arasu P T, Pillai M S and Natarajan C 1993 Talanta 401411

19. Saycee I G 1968 Talanta 151397

20. Krizek B A and Berg J M 1992 Inorg. Chem. 312984

21. Reddy P R, Sudhakar K and Adharani T K 1991 Indian J. Chem. A30 522

22. Avdeef A, Hartenstein F, Chemotti A R and Brown J A Jr 1992 Inorg. Chem. 313701

23. Sovago I, Kiss T, Varnagy K and Reverend B D 1988 Polyhedron 71089

24. Perin D D and Saycee I 1968 J. Chem. Soc. A 58

25. Gergely G A and Sovago I 1979 Metal ions in biological systems (ed.) H Sigel (New York: Marcel Dekker) vol. 9, p. 77

26. Israeli J and Saulnier H 1968 Inorg. Chim. Acta 2482

27. Tainer J A, Getzott E D, Beem K M, Richardson J S and Richardson D C 1982 J. Mol. Biol. 160181

28. Irving H M and Williams R J P 1948 Nature (London) 162746

29. Irving H M and Williams R J P 1953 J. Chem. Soc. 3192

30. Gampp H, Sigel H and Zuberbuhler A D 1982 Inorg. Chem. 211190 